\title{
"Do corporate governance and culture matter in cross-border acquisitions? Some Chinese evidence"
}

\begin{tabular}{|c|c|}
\hline AUTHORS & $\begin{array}{l}\text { Won Young Chae } \\
\text { Jinho Byun (D https://orcid.org/0000-0002-5424-3433 } \\
\text { Paul Moon Sub Choi (D https://orcid.org/0000-0003-3338-4728 } \\
\text { Ruilin Yang }\end{array}$ \\
\hline ARTICLE INFO & $\begin{array}{l}\text { Won Young Chae, Jinho Byun, Paul Moon Sub Choi and Ruilin Yang (2018). Do } \\
\text { corporate governance and culture matter in cross-border acquisitions? Some } \\
\text { Chinese evidence. Investment Management and Financial Innovations, 15(1), } \\
\text { 90-105. doi: 10.21511/imfi.15(1).2018.09 }\end{array}$ \\
\hline DOI & http://dx.doi.org/10.21511/imfi.15(1).2018.09 \\
\hline RELEASED ON & Thursday, 08 February 2018 \\
\hline RECEIVED ON & Tuesday, 24 October 2017 \\
\hline ACCEPTED ON & Thursday, 18 January 2018 \\
\hline LICENSE & $\begin{array}{l}(c)) E Y \\
\text { This work is licensed under a Creative Commons Attribution } 4.0 \text { International } \\
\text { License }\end{array}$ \\
\hline JOURNAL & "Investment Management and Financial Innovations" \\
\hline ISSN PRINT & $1810-4967$ \\
\hline ISSN ONLINE & $1812-9358$ \\
\hline PUBLISHER & LLC "Consulting Publishing Company "Business Perspectives" \\
\hline FOUNDER & LLC "Consulting Publishing Company "Business Perspectives" \\
\hline
\end{tabular}

NUMBER OF REFERENCES

27

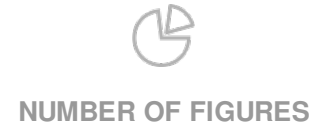

0
NUMBER OF TABLES

8

(C) The author(s) 2022. This publication is an open access article. 


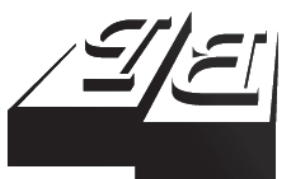

BUSINESS PERSPECTIVES

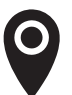

LLC "CPC "Business Perspectives" Hryhorii Skovoroda lane, 10, Sumy, 40022, Ukraine

www.businessperspectives.org

Received on: $24^{\text {th }}$ of October, 2017 Accepted on: $18^{\text {th }}$ of January, 2018

(C) Won Young Chae, Jinho Byun, Paul Moon Sub Choi, Ruilin Yang, 2018

Won Young Chae, Ph.D. Candidate, College of Business Administration Ewha Womans University, Republic of Korea.

Jinho Byun, Professor, College of Business Administration, Ewha Womans University, Republic of Korea.

Paul Moon Sub Choi, Associate Professor, College of Business Administration, Ewha Womans University, Republic of Korea.

Ruilin Yang, corresponding author, M.S. in Business Administration, College of Business Administration, Ewha Womans University, Republic of Korea.

\section{(c) (i)}

This is an Open Access article, distributed under the terms of the Creative Commons Attribution 4.0 International license, which permits unrestricted re-use, distribution, and reproduction in any medium, provided the original work is properly cited.

Won Young Chae (Korea), Jinho Byun (Korea), Paul Moon Sub Choi (Korea),

Ruilin Yang (Korea)

\title{
DO CORPORATE GOVERNANCE AND CULTURE MATTER IN CROSS-BORDER ACQUISITIONS? SOME CHINESE EVIDENCE
}

\begin{abstract}
The Chinese market for corporate control has recently gained much academic attention. This research constructs a sample of 159 cross-border acquisitions made by 123 Chinese firms between 2010 and 2014 and relates the roles of governance and culture to the wealth effects of mergers. First, the shareholders of Chinese bidders experience gains upon the announcement of overseas mergers. Second, country- and firm-level governance notably affects the cumulative abnormal returns of Chinese acquirers. Lastly, and however, the cultural distance per Hofstede's (1980) four cultural dimensions does not appear to be a significant factor in determining the shareholder wealth of Chinese purchasers.
\end{abstract}

\section{Keywords}

\section{JEL Classification}

\section{INTRODUCTION}

The Chinese market for corporate control has recently gained much academic attention. In this paper, we contribute to the literature on emerging markets finance by identifying the factors of determining the wealth of Chinese acquiring shareholders with regards to crossborder acquisitions. The global market for corporate control has been active in the past three decades. Chinese firms have begun acquiring foreign assets relatively recently, mostly since 2000 when the Chinese government initiated its "Go Global" strategy (China Council for the Promotion of International Trade, 2011). However, state-owned enterprises (SOEs) in China started overseas acquisitions as early as the 1980's.

Five discernable patterns emerge from foreign investments by Chinese companies. First, changes are in both volume (number of transactions) and quality (deal size). According to the statistics of overseas investments by Chinese firms publicized by the Chinese government since 2003, the total deal size amounted to US\$ 122.9 billion in 2014 , which is 40 times the reported value of US\$ 2.7 billion in 2002. This placed China third, after the U.S. and Japan. Also, Chinese companies made 424 overseas acquisitions in 2013 (PRC Ministry of Commerce, $2013)^{1}$. Second, private sector companies in China have also shown in-

1 http://english.mofcom.gov.cn/article/statistic/foreigninvestment/ 
creased interest in global buyouts with the help of efficient approval procedures established by the "Go Global" campaign. The split between SOEs and private sector firms in cross-border mergers, excluding financial buyers, is $1 / 3$ versus $2 / 3$ in number and $2 / 3$ versus $1 / 3$ in deal size (Pricewaterhouse Coopers, 2014). Third, the primary targets of SOEs are in the manufacturing and natural resources industries whereas those of private sector firms are in transition from conventional manufacturing to science and technology and service industries (Pricewaterhouse Coopers, 2014). Fourth, the target countries are highly diversified, 184 as of December 2013 (PRC Ministry of Commerce, 2014) ${ }^{2}$. Fifth, considering the substantial foreign exchange reserves in China, US\$ 384.3 billion as at the end of 2014, a continued escalation in cross-border corporate purchases is expected. China has shown annual trade surpluses from 2005 to 2013, except for 2011 (People's Bank of China, 2014).

As mergers by Chinese firms became conspicuously active, so did speculations and expectations of eventual successes. Boateng et al. (2008), Kling and Weitzel (2011), Ning et al. (2014), and Du and Boateng (2015) report positive cumulative abnormal returns (CARs) for Chinese shareholders upon the announcement of cross-border mergers and acquisitions. However, Chen and Young (2010) document negative event-study returns for 39 international merger cases involving Chinese SOEs. Bhagat et al. (2011) show that 68 takeovers of emerging market firms by Chinese companies are, on average, appraised as promising by investors with positive CARs. They analyze variables such as ownership structure, historical growth and operational performance, type of merger, corporate governance, and the ratio of tender offers and find that of 698 cross-border transactions for corporate control, half of the top 10 firms in terms of shareholder wealth gains are based in China.

There are two broad opinions regarding corporate purchases made by Chinese SOEs. First, Chen and Young (2010), Ning et al. (2014), and Kling and Weitzel (2011) argue that the shareholders of Chinese SOEs on average see their wealth decline when their firms acquire overseas targets because their government shareholder might make decisions from political motives at the expense of minority and individual shareholders' agency costs. Second and to the contrary, Du and Boateng (2015) find that the Chinese government's ownership and shareholders' wealth correlate positively because of the affirmative signals sent by policy-driven turnaround of targets and fewer financial restrictions because of implicit governmental guarantees. Also, most Chinese SOEs are cross-listed abroad, and those firms show higher shareholder value (Ghosh \& He, 2015) because they are believed to maintain higher managerial transparency under the regulatory umbrella of foreign authorities (Ning et al., 2014). Choi and Choi (2015) show that Korean firms that have cross-listed their American depositary receipts are better-governed than other firms, lending support to Coffee's (1999) bonding hypothesis. Kling and Weitzel (2011) find that among the $A$-shares (Shanghai and Shenzhen-listed, Chinese Yuan-denominated), $B$-shares (Shanghai and Shenzhen-listed, foreign currency-denominated), and $H$-shares (Hong Kong-listed, Hong Kong dollar-denominated) of Chinese companies, $B$ - and $H$-listings create positive event-study returns, although those results are statistically insignificant. However, the literature contains no event study of acquisitions of foreign targets by cross-listed Chinese firms. In addition to cross-country differences in corporate governance, non-economic traits such as cultural and geographical distance are known to affect the outcomes of cross-border mergers (Erel et al., 2012). None of those traits have been analyzed as they pertain to foreign acquisitions by Chinese corporations.

Regarding the effects of corporate governance on the announcement returns of mergers, legal systems (common versus civil laws), corruption rate, government efficiency, political security of the target countries (Bhagat et al., 2011; Weitzel et al., 2006), and differences in the legal enforcement between acquiring and target countries (Martynova \& Renneboog, 2008; Feito-Ruiz et al., 2011) have been previously discussed. Du and Boateng (2015) focus on the influence of the cultural distance (Hofstede, 1980) between China and target countries and the target country risk indicator on the CARs of Chinese ac-

2 http://english.mofcom.gov.cn/article/statistic/foreigninvestment/ 
quiring firms, although the cultural factor turns out to be statistically insignificant. In an attempt to improve the explanatory power of Hofstede's (1980) four cultural dimensions, Aybar and Ficici (2009) control for the geographical distance between countries. Hitherto, existing studies on Chinese acquisitions of foreign firms do not identify relevant control variables, such as regional economic development, differences in GDP growth rates, stock market performance, currency values or strengths, economic status (developed versus emerging or developing), languages, or taxes.

Can the cross-listings of Chinese SOEs play a role in determining the influence of the Chinese government's shares on positive merger announcement returns? A firm can improve its governance by listing in a country or region with better sovereign-level corporate governance than the home country (Ghosh \& He, 2015). According to the bonding hypothesis (Coffee, 1999), an emerging market firm's decision to cross-list on a developed country's exchange requires ex ante motivation that signals managerial commitment to improving corporate governance. After cross-listing, the firm has to comply with stringent internal control guidelines enforced by the foreign authority; thus the ex post disciplinary mechanism is binding.

The protection of investors' rights can be realized (Choi \& Choi, 2015). According to our hypothesis, Chinese firms that go public in the U.S., Hong Kong, or another country demonstrate better corporate governance than those listed only in Shanghai or Shenzhen and can expect high abnormal returns upon the announcement of cross-border M\&As.

H1: If a Chinese firm goes public in a country or region considered to have better corporate governance than China, such as the U.S. or Hong Kong, it can obtain higher abnormal returns than do Chinese companies listed exclusively in China.

The level of corporate governance can be used to measure the degree to which shareholders' rights are protected, so investors prefer to invest in companies with good governance. Accordingly, well-governed Chinese companies can expect higher abnormal returns than their more poorly governed counterparts when they announce international takeovers. Through the results of their study on Chinese companies' governance and performance, Cheung et al. (2010) empirically prove that good corporate governance can positively affect a company's market value, which suggests that Chinese firms with good governance will have a higher Tobin's $Q$ than do companies with lower levels of governance. Thus, according to the bootstrapping hypothesis of governance, if a target country has higher levels of governance than the mother country, an acquiring company can gain a better governance structure, and its Tobin's $Q$ will improve.

H2: If a Chinese company acquires a target company in a better-governed country, the acquirer can obtain higher abnormal returns than would otherwise be the case.

According to the positive spillover by law hypothesis suggested by Martynova and Renneboog (2008), the better the corporate governance of acquiring firms, the higher are the wealth effects shown for both the acquiring and target companies. In addition, according to the bootstrapping hypothesis, if the abnormal returns of an acquiring company increase through the acquisition of a target company with good corporate governance, the abnormal returns earned will increase as the difference between the firms' increases, regardless of whether the acquirer or the target has better corporate governance.

H3: The greater the difference in corporate governance between a target country and China, the higher are the abnormal returns for the Chinese bidding company.

If the information asymmetry problem arising from cultural distance between an acquiring country and a target country becomes serious, it can cause an increase in M\&A transaction costs. In other words, 
the cultural distance asserted by Datta et al. (1995) can pose a barrier to transactions between two countries and lead to a rise in M\&A transaction costs, which in turn negatively affect the shareholder wealth of the acquirer.

H4: The greater the cultural distance between two countries, the lower are the abnormal returns for Chinese firms.

Aybar and Ficici (2009) measure an acquiring firm's international experience using the ratio of the company's foreign trade volume to its total assets. In line with this method, the international experience in the acquiring and target countries can be measured using the ratio of foreign trade volume to GDP. In other words, countries that have been actively engaged in international trade build up international experience, which can reduce the effects of cultural distance as defined through Hofstede's four dimensions.

H5: A target country with considerable international experience can lower the negative effects of cultural distance on the abnormal returns of a Chinese purchaser.

In this paper, we construct a sample of 159 cross-border acquisitions made by 123 Chinese firms between 2010 and 2014 and relate the roles of governance and culture to the wealth effects of cross-border mergers. Our empirical findings are as follows. First, the shareholders of Chinese bidders experience gains upon the announcement of overseas mergers. Second, country- and firm-level governance significantly affects the CARs of Chinese acquirers. Specifically, the CAR increases with cross-country differences in control of corruption, governance effectiveness, political stability and absence of violence and terrorism, and regulatory quality and rule of law. At the firm-level, poorly governed Chinese acquirers in cross-border deals show higher CARs, which contradicts Masulis et al.'s (2007) U.S. study. Third, some firm-level and deal characteristics affect the event-study returns of Chinese acquiring firms, such as previous returns and listed targets negatively and deal size and percentage ownership positively. However, the CAR decreases as the bidding firm becomes more transparent. Fifth, the cultural distance per Hofstede's (1980) four cultural dimensions does not appear to be a significant factor in determining the shareholder wealth of Chinese purchasers.

In the remainder of this paper, the data, variables, and methods of our research are discussed in section 1. Section 2 presents the results of our empirical analyses. Finally, we conclude with the implications of this study and future research ideas in the last section.

\section{METHODS}

\subsection{Data}

The primary sample for our study, sourced from Wind China, is the domestic and cross-border M\&A deals of 2,209 cases involving Chinese acquiring firms from January 2010 until December 2014. After removing domestic, uncompleted, non-controlling stake (less than 50 percent ownership), and financial institution acquisitions, 254 deal counts remained. Sequentially, we excluded deals without official announcement dates via the Shanghai, Shenzhen, Hong Kong, or New York (NYSE) stock exchanges and company websites, along with those listings with daily closing stock price observations for fewer than 50 percent of the total trading days in the sample period. As a result of those qualifications, the total number of deals fell to 159 cases with 123 acquirers and 44 target countries (Table 1).

\subsection{Variables}

We measured stock returns before and after a given announcement date and used them to examine changes in the shareholder wealth upon the announcement of cross-border buyouts. The base date for the announcement of a case refers to the date on which a cross-border M\&A is first an- 
Table 1. Trends in cross-border deals announced by listed Chinese acquirers

\begin{tabular}{|c|c|c|c|c|}
\hline \multirow{2}{*}{ Year } & \multicolumn{3}{|c|}{ Exchange of acquirer listing } & \multirow{2}{*}{ Total } \\
\hline & Shanghai & Shenzhen & Foreign (cross-listing) & \\
\hline 2010 & $5(5)$ & $4(4)$ & $15(12)$ & $24(21)$ \\
\hline 2011 & $7(7)$ & $10(10)$ & $10(8)$ & $27(25)$ \\
\hline 2012 & $5(5)$ & $14(14)$ & $14(12)$ & $33(31)$ \\
\hline 2013 & $14(14)$ & $11(11)$ & $4(4)$ & $29(29)$ \\
\hline 2014 & $11(11)$ & $17(17)$ & $18(14)$ & $48(42)$ \\
\hline Total & 42 & 56 & 61 & 159 (123) \\
\hline
\end{tabular}

Note: This table shows the trends in number of cross-border merger deals announced by listed Chinese acquiring firms from 2010 until 2014. The number of acquirer is within parentheses.

nounced on the website of a stock exchange or an involved company.

\subsubsection{Cumulative abnormal return}

We carry out an event study from the base date of the M\&A announcement to analyze changes in shareholder wealth and their causes according to the timing of M\&A announcements. We use daily stock returns and market returns as a market model to explore the market reaction that measures shareholder wealth: the daily returns of the Shanghai Composite Index to estimate stock items traded in the Shanghai stock market, the daily returns of the Shenzhen Composite Index for items on the Shenzhen stock market, the Hang Seng Index for items on the Hong Kong stock market, and the Dow Jones Index for items on the U.S. stock market. We base our parameter estimation on the period 230 days to 30 days prior to the announcement of each case.

We sequentially calculate CARs by first extracting an ordinary least squares estimate of the slope coefficient $\left(\widehat{\beta}_{i}\right)$ in the following market model:

$$
R_{i t}=\alpha_{i}+\beta_{i} R_{m t}+\varepsilon_{i t}
$$

where $R_{i t}$ is the return of firm $i$ on day $t$, and $R_{m t}$ is the market return on day $t$. The abnormal return $\left(A R_{i t}\right)$ is calculated,

$$
A R_{i t}=R_{i t}-\left(\alpha_{i}+\widehat{\beta}_{i} R_{m t}\right)
$$

to give the $\left(d_{1}+d_{2}+1\right)$-day CAR upon firm $i$ 's foreign acquisition, announced on day $\tau$, as follows:

$$
C A R_{i \tau}\left[-d_{1},+d_{2}\right]=\left\{\prod_{\tau=-d_{1}}^{+d_{2}}\left(1+A R_{i \tau}\right)\right\}-1 .
$$

\subsubsection{Independent variables}

The independent variables pertaining to countryand firm-level governance are as follows.

Legal system of target countries. Based on the classification by La Porta et al. (2006), we divide the laws of each target country into English legal origin countries and German legal origin countries (Table 2). Countries that adopt the English legal system are the U.K., the U.S., Canada, Hong Kong, New Zealand, and Australia, and the countries under the German legal system are Germany, Japan, France, the Netherlands, and Italy. This variable (Legal) is a dummy variable assigned the value of one if the target country belongs to the English legal system and zero otherwise (German).

The sovereign governance index $\left(G_{j}\right)$ of each target country $(j)$ is calculated as follows:

$$
G_{j}=\sum_{i=1}^{5} N_{i j},
$$

where $N_{i j}$ are the five following factors: control of corruption, government effectiveness, regulatory quality, political stability and absence of violence and terrorism, and rule of law. This index is available from the World Bank database.

Accordingly, the relative governance (Relative $G$ ) of a target country $(j)$ over China is

$$
\text { Relative } G_{j}=\frac{\sum_{i=1}^{5} N_{i j}}{\sum_{i=1}^{5} N_{i c}},
$$

where $N_{i j}$ is the value of evaluation dimension $i$ for country $j$, and $N_{i c}$ is the value of evaluation dimension $i$ for China. 
Table 2. Cross-border acquisitions by Chinese firms by the legal systems of target countries

\begin{tabular}{|c|c|c|c|c|c|c|}
\hline \multirow[b]{2}{*}{ Country } & \multirow[b]{2}{*}{$\underset{\text { count* }}{\text { Deal }}$} & \multirow[b]{2}{*}{$\begin{array}{c}\text { Deal count as } \\
\text { a percentage of total } \\
\text { deals } \%, \%\end{array}$} & \multicolumn{4}{|c|}{ Deal value (US\$'000s) } \\
\hline & & & $\begin{array}{l}\text { Deal } \\
\text { count }\end{array}$ & $\begin{array}{l}\text { Deal count as } \\
\text { a percentage of } \\
\text { total deals, \% } \\
\end{array}$ & Total & Average \\
\hline \multicolumn{7}{|c|}{ English legal system } \\
\hline USA & 36 & 22.6 & 29 & 20.7 & 5240509.7 & 180707.2 \\
\hline Canada & 11 & 6.9 & 11 & 7.9 & 18471285.7 & 1679207.8 \\
\hline U.K. & 7 & 4.4 & 7 & 5.0 & 1471235.2 & 210176.5 \\
\hline Australia & 6 & 3.8 & 5 & 3.6 & 1080359.0 & 216071.8 \\
\hline Hong Kong & 6 & 3.8 & 6 & 4.3 & 2110062.9 & 351677.2 \\
\hline Singapore & 6 & 3.8 & 5 & 3.6 & 1174230.0 & 234846.0 \\
\hline Thailand & 2 & 1.3 & 2 & 1.4 & 7307.0 & 3653.5 \\
\hline India & 2 & 1.3 & 2 & 1.4 & 27570.0 & 13785.0 \\
\hline Ireland & 1 & 0.6 & 1 & 0.7 & 377.6 & 377.6 \\
\hline South Africa & 1 & 0.6 & 1 & 0.7 & 227000.0 & 227000.0 \\
\hline New Zealand & 1 & 0.6 & 1 & 0.7 & 56425.4 & 56425.4 \\
\hline Israel & 1 & 0.6 & 1 & 0.7 & 1272000.0 & 1272000.0 \\
\hline Virgin Islands & 1 & 0.6 & 1 & 0.7 & 5317.6 & 5317.6 \\
\hline Subtotal & 81 & 50.9 & 72 & 51.4 & 31143680.1 & 342403.5 \\
\hline \multicolumn{7}{|c|}{ German legal system } \\
\hline Germany & 15 & 9.4 & 13 & 9.3 & 1266311.1 & 97408.5 \\
\hline Japan & 9 & 5.7 & 9 & 6.4 & 358766.7 & 39863.0 \\
\hline Netherlands & 5 & 3.1 & 5 & 3.6 & 2468288.7 & 493657.7 \\
\hline Italy & 4 & 2.5 & 4 & 2.9 & 659814.6 & 164953.7 \\
\hline Argentina & 3 & 1.9 & 3 & 2.1 & 13314948.5 & 4438316.2 \\
\hline Poland & 3 & 1.9 & 1 & 0.7 & 559.5 & 559.5 \\
\hline Brazil & 2 & 1.3 & 2 & 1.4 & 162403.2 & 81201.6 \\
\hline Bolivia & 2 & 1.3 & 1 & 0.7 & 42090.0 & 42090.0 \\
\hline Denmark & 2 & 1.3 & 2 & 1.4 & 14600.0 & 7300.0 \\
\hline France & 2 & 1.3 & 1 & 0.7 & 26634.7 & 26634.7 \\
\hline Gabon & 2 & 1.3 & 2 & 1.4 & 63238.6 & 31619.3 \\
\hline Finland & 2 & 1.3 & 2 & 1.4 & 66483.3 & 33241.7 \\
\hline Congo & 2 & 1.3 & 2 & 1.4 & 88748.6 & 44374.3 \\
\hline Cambodia & 2 & 1.3 & 2 & 1.4 & 16266.1 & 8133.1 \\
\hline Czech Republic & 2 & 1.3 & 2 & 1.4 & 82191.9 & 41096.0 \\
\hline Madagascar & 1 & 0.6 & 1 & 0.7 & 12000.0 & 12000.0 \\
\hline Portugal & 3 & 1.9 & 3 & 2.1 & 2112743.9 & 704248.0 \\
\hline Switzerland & 2 & 1.3 & 2 & 1.4 & 11324.5 & 5662.3 \\
\hline Indonesia & 2 & 1.3 & 1 & 0.7 & 608.6 & 608.6 \\
\hline Arabia & 2 & 1.3 & 2 & 1.4 & 57050.0 & 28525.0 \\
\hline Austria & 1 & 0.6 & 1 & 0.7 & 6104.8 & 6104.8 \\
\hline Russia & 1 & 0.6 & 0 & 0.0 & - & - \\
\hline Kazakhstan & 1 & 0.6 & 1 & 0.7 & 37595.9 & 37595.9 \\
\hline Latvia & 1 & 0.6 & 0 & 0.0 & $-\quad-$ & - \\
\hline Peru & 1 & 0.6 & 1 & 0.7 & 2600000.0 & 2600000.0 \\
\hline Sweden & 1 & 0.6 & 1 & 0.7 & 3602.1 & 3602.1 \\
\hline Samoa & 1 & 0.6 & 1 & 0.7 & 6959.8 & 6959.8 \\
\hline Taiwan & 1 & 0.6 & 1 & 0.7 & 50609.6 & 50609.6 \\
\hline Turkey & 1 & 0.6 & 1 & 0.7 & 170.5 & 170.5 \\
\hline Uruguay & 1 & 0.6 & 0 & 0.0 & - & - \\
\hline Chile & 1 & 0.6 & 1 & 0.7 & 14280.0 & 14280.0 \\
\hline Subtotal & 78 & 49.1 & 68 & 48.6 & 23544395.2 & 281900.5 \\
\hline Total & 159 & - & 140 & - & 54688075.3 & 313252.6 \\
\hline
\end{tabular}

Note: Based on La Porta et al's (2006) classification, the laws of target countries are grouped into English versus German legal origins. Deal counts in number and percentage with asterisk $\left({ }^{*}\right)$ are those without deal value disclosure. 
We use the computational model for cultural distance from existing studies to calculate the distance of governance ( $G$ Distance) between China and a target country. That is,

$$
G \text { Distance }_{j}=\frac{\sum_{i=1}^{5}\left\{\left(N_{i j}-N_{i c}\right)^{2}\right\}}{5 V_{i}},
$$

where $G D_{j}$ is the governance index distance between China and country $j ; N_{i j}$ is the value of evaluation dimension $i$ for country $j ; N_{i c}$ is the value of evaluation dimension $i$ for China; and $V_{i}$ is the distribution of evaluation dimension $i$.

Because higher corporate transparency leads to lower information asymmetry inside and outside a company, stock prices are effectively determined, and therefore the explanatory power for the stock returns of a transparent company (coefficient of determination, $R$-square or $R^{2}$ ) should be low (Mørck et al., 2000). Accordingly, we define stock return synchronicity as a log it transformation of $R$-square from the regression of the market model $\left(\ln \left(\frac{R^{2}}{1-R^{2}}\right)\right)$, porate transparency and corporate governance. We follow the convention of Chen et al. (2007) for the firm-level governance score (Firm $G$ ) as

$$
\text { Firm } G=1-R^{2}
$$

where $R^{2}$ is the $R$-square from the regression of the market model (1).

The cultural distance (C Distance) between two countries is based on Hofstede's (1980) four dimensions of power (distance, individualism, masculinity, and uncertainty avoidance) and is measured by combining evaluation dimensions (Kogut \& Singh, 1988; Malhotra et al., 2011; Slangen, 2006) as follows:

$$
{\text { C } \text { Distance }_{j}}=\frac{\sum_{i=1}^{4}\left\{\left(N_{i j}-N_{i c}\right)^{2}\right\}}{4 V_{i}},
$$

where $C$ Distance $_{j}$ is the cultural distance between China and country $j ; H_{i j}$ is the value of evaluation dimension $i$ for country $j ; H_{i c}$ is the value of evaluation dimension $i$ for China; and $V_{i}$ is the distribution of evaluation dimension $i$.

\subsubsection{Control variables}

This section lists the control variables of our research, which we selected following the literature. The firm-level characteristics are as follows: Cross-listed status of the acquiring firm (Cross Listed) is assigned the value one if a Chinese acquirer is listed on an overseas stock exchange (Hong Kong or the U.S.), and zero otherwise. State ownership (State Own) classifies Chinese firms by whether their major shareholder is the state. An acquiring firm with high future growth potential can create new opportunities and markets through cross-border takeovers and help increase its shareholders' wealth with a high Tobin's Q (Tobin Q) (Ning et al., 2014; Kling \& Weitzel, 2011). Pre-performance (Pre Perform) is obtained from the annual accounts of each acquiring firm for the year prior to the M\&A transaction. Corporate size (Size) is derived by taking the logarithm of observations obtained from the annual accounts of each acquiring firm for the year prior to the M\&A transaction. Leverage ratio (Leverage) can reveal the financial capacity of acquiring companies, reduce the agency problem, and positively influence the wealth of the acquiring shareholders. We obtain this variable from the annual accounts of each acquiring firm for the year prior to the M\&A transaction. Free cash flow to assets ratio (Free Cash Flow) is obtained from dividing a company's actual cash flow that the firm can use by deducting capital expenditures and additional working capital from the operational cash flow obtained through business activities, and by normalizing this measure with the size of total assets. Corporate age (Age) is measured as the number of years from foundation until the M\&A event. Track record (Experience) as the firm's experience in buyouts in a target area prior to a particular transaction is obtained through the websites of the acquiring companies and Internet searching.

We also control for deal characteristics as follows: Deal size (Deal Size) defines transaction costs as the relative value of an acquirer's total assets (Kling \& Weitzel, 2011). Relatedness (Related) measures how well an acquiring company's business activities relate to those of its target, an acquisition can be classified as related 
or unrelated, obtained from M\&A announcement reports. Payment method (Payment) is obtained from M\&A announcement reports as cash payment rather than stock payment appears to have positive effects on the shareholder wealth in acquiring companies. Purchase ratio (Control) is the acquisition stake at the target firm. Acquiring a listed company (Listed Target) can result in high political costs, and the target can demand a high premium, which in turn can negatively affect the wealth of the bidding company's shareholders.

We provide a list of country-level control characteristics as follows: Tax (Tax) is a dummy variable equal to one if the ratio of the target country's corporate tax rate over that of China is higher than one and zero otherwise, obtained from the KPMG website. In the literature, considerable efforts have been made to analyze the effects of geographical distance between countries (Geo Distance) (Aybar \& Ficici, 2009). In line with the method applied in Aybar and Ficici (2009) that defines the international experience of target companies (International) using the ratio of their foreign trade volume to total assets, we evaluate the international experience of acquiring and target countries through the ratio of their foreign trade volume to GDP.

Table 3 summarizes the variables of our investigation and their expected signs in affecting the CAR of Chinese acquirers upon the announcement of foreign acquisitions.
Table 3. Variables

\begin{tabular}{|c|c|c|}
\hline Variable & Abbreviation & $\begin{array}{c}\text { Expected } \\
\text { sign }\end{array}$ \\
\hline \multicolumn{3}{|c|}{$\begin{array}{r}\text { Dependent variable } \\
\end{array}$} \\
\hline Cumulative abnormal return & CAR & \\
\hline \multicolumn{3}{|c|}{ Independent variables } \\
\hline \multicolumn{3}{|c|}{ Governance measures } \\
\hline Legal system of target country & Legal & + \\
\hline \multicolumn{3}{|l|}{ Sovereign governance index } \\
\hline Relative governance & Relative G & + \\
\hline Governance distance & G Distance & + \\
\hline Corporate governance & Firm G & - \\
\hline \multicolumn{3}{|c|}{$\begin{array}{l}\text { Culture measures } \\
\end{array}$} \\
\hline \multicolumn{3}{|l|}{ Cultural index } \\
\hline Cultural distance & C Distance & - \\
\hline \multicolumn{3}{|c|}{\begin{tabular}{|c|} 
Control variables \\
\end{tabular}} \\
\hline \multicolumn{3}{|c|}{ Firm-level characteristics } \\
\hline Cross-listed status & Cross Listed & + \\
\hline State ownership & State Own & \\
\hline Tobin's Q & Tobin Q & \\
\hline Pre-performance & Pre Perform & + \\
\hline Corporate size & Size & \\
\hline Leverage ratio & Leverage & + \\
\hline Free cash flow to assets ratio & $\begin{array}{l}\text { Free Cash } \\
\text { Flow }\end{array}$ & \\
\hline Corporate age & Age & + \\
\hline Track record & Experience & + \\
\hline Listed target & Listed Target & - \\
\hline \multicolumn{3}{|l|}{ Deal characteristics } \\
\hline Deal size & Deal Size & \\
\hline Relatedness & Related & + \\
\hline Payment method & Payment & + \\
\hline Purchase ratio & Control & + \\
\hline \multicolumn{3}{|l|}{ Country-level characteristics } \\
\hline Tax & Tax & - \\
\hline Geographical distance & Geo Distance & - \\
\hline $\begin{array}{l}\text { International experience of } \\
\text { target country }\end{array}$ & International & + \\
\hline
\end{tabular}

Note: This table lists the variables selected and identified in this research.

\subsection{Empirical model}

Based on the variables described in the previous sections, our general empirical model in this research is as follows:

$$
\begin{aligned}
& \operatorname{CAR}_{i \tau}\left[-d_{1},+d_{2}\right]=\text { Intercept }+\underbrace{a_{1} \text { Legal }_{i, t}+a_{2} \text { Relative }_{i, t}+a_{3} \text { GDistance }_{i, t}+a_{4} \text { Firm }_{i, t}+a_{5} \text { CrossListed }_{i, t}}_{\text {Governance measures }}+ \\
& +\underbrace{b_{1} \text { C } \text { Distance }_{i}}_{\text {Cultural measure }}+c_{1} \text { State Own } n_{i, t}+c_{2} \text { Tobin }_{i, t-1}+c_{3} \text { Pre Perform } \text { Pitt-1 }_{4}+c_{4} \text { Size }_{i, t-1}+c_{5} \text { Leverage }_{i, t-1}+
\end{aligned}
$$

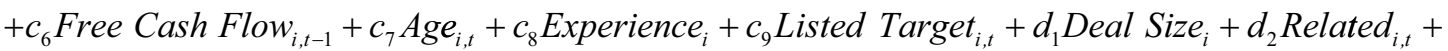

$$
\begin{aligned}
& +d_{3} \text { Payment }_{i, t}+d_{4} \text { Control }_{i, t}+e_{1} \text { Tax }_{i, t}+e_{2} \text { Geo Distance }_{i}+e_{3} \text { International }_{i, t}+\text { error term }
\end{aligned}
$$

whose dependent variable is the $\left(d_{1}+d_{2}+1\right)$-day CAR for firm $i$ 's foreign acquisition announced on day $\tau$ in year $t$. 
Table 4. Cumulative abnormal returns for Chinese acquirers

\begin{tabular}{|c|c|c|c|c|c|c|c|}
\hline Window & Day 0 & {$[-5,-1]$} & {$[-1,+1]$} & {$[-2,+2]$} & {$[-3,+3]$} & {$[-5,+5]$} & {$[+1,+5]$} \\
\hline CAR & $0.007^{* *}$ & 0.0014 & $0.014^{* * *}$ & $0.011^{* *}$ & 0.009 & 0.010 & 0.001 \\
\hline t-value & 2.017 & 0.299 & 2.953 & 2.150 & 1.505 & 1.493 & 0.250 \\
\hline
\end{tabular}

Note: This table reports the cumulative abnormal returns (CARs) for Chinese acquirers upon their announcement of 159 crossborder merger deals. CAR reported as 0.007 correspond to $.70 \%$. Asterisks denote the significance of CAR estimates: ${ }^{\star} \mathrm{p}<0.1$, ${ }^{* *} \mathrm{p}<0.05,{ }^{* * *} \mathrm{p}<0.01$

\section{RESULTS}

\subsection{Preliminary results}

\subsubsection{Cumulative abnormal returns}

The CARs for Chinese acquirers after measuring market responses before and after the announcements of 159 cases of cross-border mergers are given in Table 4. Observation sections are set to both asymmetric and symmetric event windows $([-5,-1],[-1,+1],[-2,+2],[-3,+3],[-5,+5]$, and $[+1,+5])$ and the results are positive in all sections. This result is consistent with those of Boateng et al. (2008), Kling and Weitzel (2011), Ning et al. (2014), and Du et al. (2015). Moreover, the abnormal returns on the announcement day, 3 -day $([-1,+1])$, and 5 -day $([-2,+2])$ CARs are significant: 0.7 percent, 1.36 percent, and 1.1 percent, respectively. Therefore, cross-border acquisitions by Chinese firms appear to increase the wealth of their shareholders.
Table 5 compares CARs upon announcement, classifying the events by considering whether the Chinese acquiring firm is cross-listed in the U.S. or Hong Kong and whether the target country is under the English legal system. Cross-listed Chinese firms showed higher CARs than non-cross-listed Chinese firms in all event sections. This supports our hypothesis about cross-listing, H1, showing that Chinese firms listed in the U.S. or Hong Kong earned higher abnormal returns than those listed only in Shanghai or Shenzhen.

,Also, abnormal returns for acquiring companies when the target countries are under the English legal system are higher than those when the target countries are under systems with other legal origins in all event sections. This result coincides with the studies of La Porta et al. (2006) and Bhagat et al. (2011), which claim that compared with other legal systems, English law features higher information transparency and stronger investor protection through stricter regulation of stock markets and, therefore, increases the abnormal returns of acquiring companies.

Table 5. Cumulative abnormal returns for Chinese acquirers, continued

\begin{tabular}{|c|c|c|c|c|}
\hline \multirow{2}{*}{ Window } & \multicolumn{2}{|c|}{ Cross-listed status of acquirers } & \multicolumn{2}{|c|}{ Legal system of target countries } \\
\hline & Cross-listed & Domestically listed & English legal system & German legal system \\
\hline \multicolumn{5}{|c|}{ Day 0} \\
\hline CAR & 0.012 & 0.004 & 0.012 & 0.001 \\
\hline t-value & 1.557 & 1.312 & 2.092 & 0.407 \\
\hline \multicolumn{5}{|c|}{$[-1,+1]$} \\
\hline CAR & $0.017 *$ & $0.011^{* * *}$ & $0.021^{* * *}$ & 0.006 \\
\hline t-value & 1.714 & 2.788 & 2.643 & 1.386 \\
\hline \multicolumn{5}{|c|}{$[-2,+2]$} \\
\hline CAR & 0.013 & $0.009 *$ & $0.017^{* *}$ & 0.004 \\
\hline t-value & 0.017 & 1.849 & 2.108 & 0.660 \\
\hline \multicolumn{5}{|c|}{$[-5,+5]$} \\
\hline CAR & 0.011 & 0.008 & 0.011 & 0.007 \\
\hline t-value & 0.786 & 1.060 & 1.056 & 0.737 \\
\hline
\end{tabular}

Note: This table reports the cumulative abnormal returns (CARs) for Chinese acquirers upon their announcement of 159 crossborder merger deals. Further, differences are contrasted based on the cross-listed (U.S. or Hong Kong) status of acquirers and the legal system (English versus German) of target countries. Cross-listed Chinese firms showed higher CARs than non-crosslisted Chinese firms in all event sections. Asterisks denote the significance of CAR estimates: ${ }^{*} p<0.1,{ }^{* *} p<0.05,{ }^{* * *} p<0.01$. 


\subsubsection{Sample statistics and correlation coefficients}

Table 1A (Appendix A) presents basic statistics for the variables analyzed in this paper. The mean value of relative governance (Relative $G$ ) for China and the target countries is 0.951 , and most of the targets of Chinese buyouts seem to be located in countries in which corporate governance is better than it is in China. The mean values of governance distance (G Distance) and cultural distance (C Distance) between China and the target countries are 14.449 and 10.980, respectively. Clearly, governance distance and cultural distance exist between them. According to our analysis of deal characteristics, Chinese firms prefer to pay in cash for international M\&A deals, and the bulk of the takeover deals occur between companies in related industries.

Table 2A (Appendix A) presents Pearson's correlations for all pair-wise variables. We analyzed the correlations in the order of our hypotheses: cross-listing, corporate governance and cultural distance. In the correlation analysis for crosslisting, cross-listed Chinese firms and their firm governance (Firm $G$ ) show significantly positive correlations. This result overlaps with $H 1$, which mentions that cross-listed companies tend to show better corporate governance than do non-crosslisted ones. Analyses of the correlations of crosslisting with SOEs and corporate age turn out to be both positive and highly significant, indicating that SOEs and older Chinese firms tend to crosslist. Moreover, deal characteristics for cross-border acquisitions made by cross-listed firms show significantly positive correlation between present cross-listing and prior experience with cross-border M\&As. Transaction costs and cash payment have a negative and significant correlation.

In the governance analysis, an English legal system and the governance distance between merging parties are significantly and positively correlated. That is, the governance distance between China and the target countries is greater when the targets have English legal origins. The cultural distances between English-legal-origin countries and China are significantly negative, which means the differences in cultural aspects between them are rather trivial.
In the case of relative governance and governance distance, both have significantly positive associations with cultural distance. Correlation analyses suggest that cultural distance and the target countries' level of international experience (foreign trade volume/GDP) are associated negatively and highly significantly. This accords with $H 5$, which posits that the cultural distance between two countries decreases as the target country's level of international experience increases. Also, the geographical distance between countries shows a significant and positive correlation.

\subsection{Main results}

Table 3A (Appendix A) presents the regresf sion results of 3 -day $([-1,+1])$ and 5-day $([-2,+2])$ CARs, which are the statistically significant estimates on average (Table 4$)^{3}$. Model 1 tests the hypothesis on cross-listing (H1). Model 2 verifies the hypothesis pertaining to the relative governance between countries (H2). Model 3 tests the hypothesis pertaining to the governance distance between pair-wise countries (H3). Model 4 evaluates the hypothesis pertaining to the cultural distance $(\mathrm{H} 4)$, and Model 5 examines the hypothesis regarding the cultural distance between two countries controlling for geographical distance and the target country's level of international experience (H5). Model 6 provides a comprehensive analysis of all variables used in this research.

\subsubsection{Firm-level and deal characteristics}

We implement regressions of the CAR estimates onto firm-level and deal characteristics in Model 1. Despite weak numerical significances on average, shareholders of Chinese acquirers cross-listed in the U.S. and Hong Kong (Cross Listed) appear to gain more wealth than shareholders of Chinese acquirers not cross-listed upon announcements of foreign takeovers. This is not evidence against the hypothesis on crosslisting (H1). Acquirers' previous performance (Pre Perform, previous net gain and sales) is shown to negatively affect the CAR upon merg-

3 We excluded 19 merger deals for which we could not identify transaction amounts, as well as two cases for which we could not find the purchase ratio. This brought the number of samples used for $\mathrm{H} 1$, the hypothesis on cross-listing, to 138 . 
er announcement. Although this might be unexpected, the management of a company with superior past performance, in terms of ROE, is more likely to make unreasonable decisions and overpay a premium to reach a deal, causing the value for its shareholders to wane (Du \& Boateng, 2015). Also, this result is in line with Ning et al.'s (2014) finding of a statistically significantly negative correlation between the ROA of Chinese acquirers and their CARs. If the foreign target firm is listed, it might undermine the wealth of Chinese acquiring shareholders over a 5 -day event window $([-2,+2])$, because greater political costs and a higher premium are required to secure the deal.

Regarding the deal characteristics, the deal size positively affects the CAR over 3 days $([-1,+1])$ around the announcement because larger M\&A deals (Deal Size) receive more market attention, consistent with Kling and Weitzel (2011). Paying for deals in cash does make Chinese purchasers wealthier (3-day window, $[-1,+1]$ ) which makes sense because acquirers paying in stock tend to extend higher premiums to their targets. Over 5 days surrounding the announcement $([-2,+2])$, the higher the portion of acquisition, the better is the market response (Control).

\subsubsection{Corporate governance}

While continuing to control for firm-level and deal characteristics, we test the role of corporate governance in influencing the wealth of acquiring shareholders upon a cross-border merger announcement ( $\mathrm{H} 2$ and $\mathrm{H} 3$ ) in Models 2 and $3^{4}$. Chinese firms' level of governance (Firm $G$ ) appears to significantly and negatively affect CARs over 5 days $([-2,+2])$. In other words, the shareholder value of well-governed Chinese acquiring firms diminishes upon foreign takeovers. Although this outcome contradicts Masulis et al.'s (2007) U.S. study, it is in line with Chang et al.'s (2015) international finding: "Poorly governed acquirers in crossborder deals experience higher announcement period returns". Other cross-country difference measures pertaining to governance (Relative $G$ and $G$ Distance) do not have statistically meaningful implications.

After controlling for all cultural measures, firm-level, deal, and country-level characteristics in Model 6, we find that the governance distance (G Distance) between the two involved countries positively affects the CAR over 3 days $([-1,+1])$, supporting $H 3$. In other words, the wealth of acquiring shareholders becomes higher as the cross-country difference in countrylevel governance increases. This lends support to Martynova and Renneboog's (2008) synthesis of the positive spillover by law hypothesis and the bootstrapping hypothesis, suggesting governance transfer upon merger.

\subsubsection{Cultural distance}

We turn to examining the effect of cultural distance on the acquirer's CAR ${ }^{5}$. We hypothesize a negative association between the cultural distance between the involved countries and the CAR of the Chinese acquiring shareholders (H4 and H5). In Model 4, without governance measures, the cultural distance and the CAR are positively but statistically insignificantly related. Further controlling for the geographical distance between China and the target country, the cultural distance factor continues to be insignificant. However, this result, appealing to the 'null' hypothesis, is in fact in line with the literature, which documents that in the emerging markets (Bhagat et al., 2011; Aybarand Ficici, 2009), including China ( $\mathrm{Du} \&$ Boateng, 2015), the cultural distance per Hofstede (1980) does not appear to determine the acquiring shareholders' wealth upon takeover announcement. We bring back the governance measures in Model 6, and the cultural distance remains weak but the sign turns negative. Economic intuition suggests that the gap in culture between China and a target country can pose a barrier in cross-border transactions that increases the deal costs and negatively affects the wealth of acquiring shareholders.

4 We were able to procure sovereign governance index scores (SovereignG) for 43 countries, with the exception of Congo. After excluding two cases of transactions in Congo, the final number of cases applied in the regression analysis on governance structure was 136.

5 As for samples related to cultural distance, we excluded cases in countries for which we could not identify a culture index: British Virgin Islands ( 1 case), Bolivia ( 2 cases), Gabon (2 cases), Congo ( 2 cases), Cambodia ( 2 cases), Madagascar (1 case), Kazakhstan (1 case), and Samoa (1 case). Thus, the number of samples used in the regression analysis on cultural distance was 122. 


\section{CONCLUSION}

For this paper, we have constructed a sample of 159 cross-border acquisitions made by 123 Chinese firms between 2010 and 2014 and correlated the roles of governance and culture to the wealth effects of Chinese acquisition of cross-border targets. This study has a few limitations. First, it lacks information regarding the corporate governance of the foreign target companies, which could reveal more detailed roles for how the corporate governance of the merging parties affects shareholder value. Second, we have not considered the long-term stock performances of the Chinese acquirers, which could pose an interesting research angle. M\&As are a long-run investment decision that necessitates prudent postmerger integration processes.

\section{ACKNOWLEDGEMENT}

Special thanks are due to Seung-Ho Choi, Suresh Radhakrishnan, David Reeb, and Heng-fu Zou. We thank Joonsung Won for his excellent research assistance. This research is based on Yang's M.S. thesis approved at Ewha Womans University. Standard disclaimer rules apply, and all errors are our own.

\section{REFERENCES}

1. Aybar, B., \& Ficici, A. (2009).

Cross-border acquisitions and firm value: An analysis of emerging-market multinationals. Journal of International Business Studies, 40(8), 1317-1338. https:// doi.org/10.1057/jibs.2009.15

2. Bhagat, S., Malhotra, S., \& Zhu, P. (2011). Emerging country cross-border acquisitions: Characteristics, acquirer returns and cross-sectional determinants. Emerging Markets Review, 12(3), 250-271. https://doi.org/10.2139/ ssrn. 1571349

3. Boateng, A., Qian, W., \& Tianle, Y. (2008). Cross-border M\&As by Chinese firms: An analysis of strategic motives and performance. Thunderbird international business review, 50(4), 259-270. https://doi. org/10.1002/tie.20203

4. Chang, C., Choi, P. M. S., \& Huang, S. H. (2015). Do Poorly Governed Acquirers Transfer Wealth to Targets in Cross-Border Acquisitions? Financial Management, 44(3), 475-498. https://doi.org/10.1111/ fima. 12082

5. Chen, Y. Y., \& Young, M. N. (2010). Cross-border mergers and acquisitions by Chinese listed companies: A principal-principal perspective. Asia Pacific Journal of Management, 27(3), 523-539. https://doi.org/10.1007/s10490009-9150-7

6. Cheung, Y. L., Jiang, P., Limpaphayom, P., \& Lu, T. (2010). Corporate governance in China: A step forward. European Financial Management, 16(1), 94-123. https://doi.org/10.1111/j.1468036x.2008.00446.x

7. China Council for the Promotion of International Trade (2011). Survey on current conditions and intention of outbound investment by Chinese enterprises (20082010). Retrieved from http://trade. ec.europa.eu/doclib/docs/2010/ may/tradoc_146193.pdf

8. Choi, J. H., \& Choi, P. M. S. (2015). Corporate Governance and Depositary Receipts: Evidence from Korean Stock Listings (in Korean). Korean Journal of Financial Studies, 44(2), 345-373. Retrieved from http://uci.or.kr/G704SER000000670.2015.44.2.003

9. Coffee, Jr, J. C. (1998). Future as history: The prospects for global convergence in corporate governance and its implications. Nw. UL Rev., 93, 641. https://doi. org/10.2139/ssrn.142833

10. Datta, D. K., \& Puia, G. (1995). Cross-border acquisitions: An examination of the influence of relatedness and cultural fit on shareholder value creation in US acquiring firms. MIR: Management International Review, 337-359. https://doi.org/10.1016/j. mulfin.2012.06.007

11. Du, M., \& Boateng, A. (2015). State ownership, institutional effects and value creation in crossborder mergers \& acquisitions by Chinese firms. International Business Review, 24(3), 430-442. https://doi.org/10.1016/j.ibusrev.2014.10.002

12. Erel, I., Liao, R. C., \& Weisbach, M. S. (2012). Determinants of cross-border mergers and acquisitions. The Journal of Finance, 67(3), 1045-1082. https://doi.org/10.1111/j.15406261.2012.01741.x

13. Feito-Ruiz, I., \& MenéndezRequejo, S. (2011). Cross-border mergers and acquisitions in different legal environments. International review of law and economics, 31(3), 169-187. https:// doi.org/10.1016/j.irle.2011.05.002

14. Ghosh, C., \& He, F. (2015). Investor Protection, Investment Efficiency and Value: The Case of Cross-Listed Firms. Financial Management, 44(3), 499546. https://doi.org/10.1111/ fima. 12076 
15. Hofstede, G. (1984). Culture's consequences: International differences in work-related values. https://doi.org/10.1016/03772217(82)90018-2

16. Kling, G., \& Weitzel, U. (2011). The internationalization of Chinese companies: firm characteristics, industry effects and corporate governance. Research in International Business and Finance, 25(3), 357-372. https://doi.org/10.1016/j. ribaf.2011.03.002

17. Kogut, B., \& Singh, H. (1988). The effect of national culture on the choice of entry mode. Journal of international business studies, 19(3), 411-432. https:// doi.org/10.1057/palgrave. jibs.8490394

18. Malhotra, S., Sivakumar, K., \& Zhu, P. (2011). Curvilinear relationship between cultural distance and equity participation: An empirical analysis of crossborder acquisitions. Journal of International Management, 17(4), 316-332. https://doi.org/10.1016/j. intman.2011.06.001
19. Martynova, M., \& Renneboog, L. (2008). Spillover of corporate governance standards in crossborder mergers and acquisitions. Journal of Corporate Finance, 14(3), 200-223. https://doi.org/10.4337/9781849807081.00010

20. Masulis, R. W., Wang, C., \& Xie, F. (2007). Corporate governance and acquirer returns. The Journal of Finance, 62(4), 1851-1889. https:// doi.org/10.2139/ssrn.697501

21. Mørck, R., \& Yeung, B. (1992). Internalization: an event study test. Journal of international economics, 33(1), 41-56. https://doi. org/10.1016/0022-1996(92)90049-P

22. Ning, L., Kuo, J. M., Strange, R., \& Wang, B. (2014). International investors' reactions to cross-border acquisitions by emerging market multinationals. International Business Review, 23(4), 811-823. https://doi.org/10.1016/j.ibusrev.2013.12.003

23. Porta, R., Lopez-de-Silanes, F., \& Shleifer, A. (2006). What works in securities laws? The Journal of Finance, 61(1), 1-32. https://doi. org/10.3386/w9882
24. PRC Ministry of Commerce (n.d.) Joint report on statistics of China's outbound FDI 2013, 2014. Retrieved from http://english.mofcom.gov. $\mathrm{cn} /$ article/newsrelease/significantnews/201409/20140900727958. shtml

25. Pricewaterhouse Coopers (2014). PwC M\&A 2014 review and 2015 outlook of China-the mainland of China. Retrieved from https:// www.pwchk.com/en/mergersand-acquisitions/ma-press-briefing-jan2015.pdf

26. Slangen, A. H. (2006).

National cultural distance and initial foreign acquisition performance: The moderating effect of integration. Journal of World Business, 41(2), 161170. https://doi.org/10.1016/j. jwb.2006.01.003

27. Weitzel, U., \& Berns, S. (2006). Cross-border takeovers, corruption, and related aspects of governance. Journal of International Business Studies, 37(6), 786-806. https:// doi.org/10.1057/palgrave. jibs. 8400225 


\section{APPENDIX A}

Table 1A. Summary statistics

\begin{tabular}{|c|c|c|c|c|}
\hline Variable & Mean & Standard dev. & Minimum & Maximum \\
\hline \multicolumn{5}{|c|}{ Dependent variable } \\
\hline CAR $[-1,+1]$ & 0.014 & 0.058 & -0.180 & 0.367 \\
\hline CAR $[-2,+2]$ & 0.010 & 0.062 & -0.175 & 0.294 \\
\hline \multicolumn{5}{|c|}{ Governance measures } \\
\hline Legal & 0.574 & 0.497 & 0.000 & 1.000 \\
\hline Relative G & 0.951 & 0.217 & 0.000 & 1.000 \\
\hline G Distance & 14.449 & 5.823 & 0.400 & 24.200 \\
\hline Firm G & 0.719 & 0.187 & 0.235 & 1.000 \\
\hline \multicolumn{5}{|c|}{ Cultural measure } \\
\hline C Distance & 10.980 & 4.158 & 0.570 & 19.970 \\
\hline \multicolumn{5}{|c|}{ Firm-level characteristics } \\
\hline Cross Listed & 0.361 & 0.482 & 0.000 & 1.000 \\
\hline State Own & 0.344 & 0.477 & 0.000 & 1.000 \\
\hline Tobin Q & 1.320 & 1.185 & 0.020 & 9.016 \\
\hline Pre Perform & 0.091 & 0.159 & -0.674 & 0.542 \\
\hline Size & 4.991 & 0.749 & 3.559 & 7.163 \\
\hline Leverage & 0.445 & 0.237 & 0.040 & 0.886 \\
\hline Free Cash Flow & 0.218 & 0.175 & 0.000 & 0.773 \\
\hline Age & 20.041 & 12.061 & 4.000 & 86.000 \\
\hline Experience & 0.254 & 0.437 & 0.000 & 1.000 \\
\hline Listed Target & 0.156 & 0.364 & 0.000 & 1.000 \\
\hline \multicolumn{5}{|c|}{ Deal characteristics } \\
\hline DealSize & 0.174 & 0.572 & 0.000 & 5.055 \\
\hline Related & 0.975 & 0.156 & 0.000 & 1.000 \\
\hline Payment & 0.918 & 0.275 & 0.000 & 1.000 \\
\hline Control & 0.858 & 0.192 & 0.500 & 1.000 \\
\hline \multicolumn{5}{|c|}{ Country-level characteristics } \\
\hline $\operatorname{Tax}$ & 0.680 & 0.468 & 0.000 & 1.000 \\
\hline Geo Distance & 8434.905 & 3724.632 & 1720.200 & 19273.300 \\
\hline International & 90.124 & 103.771 & 24.512 & 458.332 \\
\hline
\end{tabular}

Note: This table provides the sample statistics of variables indentified and selected in this research. Variable definitions are detailed in section 2.2. 


\begin{tabular}{|c|c|c|c|c|c|c|c|c|c|c|c|c|c|c|c|c|c|c|c|c|c|c|c|}
\hline Variable & $\frac{\underset{+1}{+1}}{\frac{\sigma o}{\delta}}$ & $\frac{\pi}{\frac{\pi}{+1}}$ & ס્త్ర & 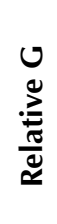 & 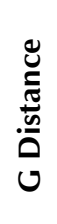 & $\underset{\mathfrak{E}}{\underline{E}}$ & 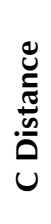 & 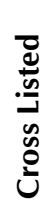 & 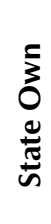 & $\begin{array}{l}\alpha \\
\therefore \\
\frac{1}{0} \\
-0\end{array}$ & 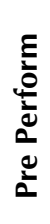 & $\stackrel{\tilde{N}}{\mathrm{n}}$ & 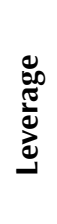 & 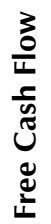 & 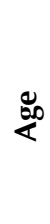 & 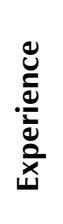 & 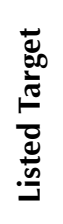 & $\frac{\stackrel{N}{N}}{\frac{\pi}{\Xi}}$ & 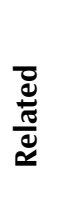 & 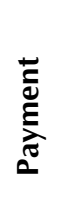 & 竞 & $\stackrel{\text { }}{\stackrel{\varpi}{F}}$ & 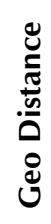 \\
\hline
\end{tabular}

\begin{tabular}{|c|c|c|c|c|c|c|c|c|c|c|c|c|c|c|c|c|c|c|c|c|c|c|c|}
\hline $\operatorname{CAR}[-2,+2]$ & $0.59^{* * *}$ & - & - & - & - & - & - & - & - & - & - & - & - & - & - & - & - & - & - & - & - & - & - \\
\hline Legal & 0.03 & 0.12 & - & - & - & - & - & - & - & - & - & - & - & - & - & - & - & - & - & - & - & - & - \\
\hline Relative G & 0.00 & 0.00 & 0.11 & - & - & - & - & - & - & - & - & - & - & - & - & - & - & - & - & - & - & - & - \\
\hline G Distance & 0.05 & 0.08 & $0.15^{*}$ & $0.52 * * *$ & - & - & - & - & - & - & - & - & - & - & - & - & - & - & - & - & - & - & - \\
\hline Firm G & 0.00 & 0.03 & 0.07 & 0.07 & 0.03 & - & - & - & - & - & - & - & - & - & - & - & - & - & - & - & - & - & - \\
\hline C Distance & 0.08 & 0.04 & $-0.16^{*}$ & $0.27 * *$ & $0.21 * *$ & -0.04 & - & - & - & - & - & - & - & - & - & - & - & - & - & - & - & - & - \\
\hline Cross Listed & 0.00 & 0.00 & -0.01 & -0.14 & -0.07 & $0.40^{* * *}$ & 0.03 & - & - & - & - & - & - & - & - & - & - & - & - & - & - & - & - \\
\hline State Own & 0.13 & 0.06 & -0.11 & $-0.23^{* * *}$ & -0.12 & 0.03 & 0.03 & $0.25^{* * *}$ & - & - & - & - & - & - & - & - & - & - & - & - & - & - & - \\
\hline Tobin Q & $-0.17^{*}$ & -0.12 & -0.08 & 0.07 & 0.05 & -0.08 & 0.09 & -0.06 & -0.03 & - & - & - & - & - & - & - & - & - & - & - & - & - & - \\
\hline Pre Perform & $-0.35^{* * *}$ & $-0.18^{* *}$ & -0.06 & 0.13 & 0.10 & $-0.28^{* * *}$ & 0.08 & -0.07 & $-0.28 * * *$ & 0.15 & - & - & - & - & - & - & - & - & - & - & - & - & - \\
\hline Size & 0.02 & $-0.22^{* *}$ & 0.01 & $-0.17^{*}$ & -0.08 & -0.09 & -0.03 & $0.36^{* * *}$ & $0.29^{* * *}$ & $-0.18^{* *}$ & 0.12 & - & - & - & - & - & - & - & - & - & - & - & - \\
\hline Leverage & 0.02 & -0.08 & 0.04 & 0.09 & -0.02 & $0.20^{* *}$ & -0.09 & $0.16^{*}$ & $0.26^{* * *}$ & -0.13 & 0.00 & $0.59^{* * *}$ & - & - & - & - & - & - & - & - & - & - & - \\
\hline $\begin{array}{l}\text { Free Cash } \\
\text { Flow }\end{array}$ & 0.09 & $0.17^{*}$ & -0.11 & 0.11 & -0.04 & -0.08 & 0.09 & -0.01 & -0.10 & 0.08 & $0.19^{* *}$ & $-0.27 * * *$ & $: 0.29 * *$ & - & - & - & - & - & - & - & - & - & - \\
\hline Age & -0.11 & -0.03 & 0.01 & -0.01 & 0.00 & $0.17^{*}$ & 0.03 & $0.42^{* * *}$ & $0.17^{*}$ & 0.03 & 0.02 & $0.18^{*}$ & 0.07 & $-0.21^{*}$ & - & - & - & - & - & - & - & - & - \\
\hline Experience & -0.09 & -0.04 & 0.12 & 0.05 & 0.08 & 0.09 & -0.13 & $0.23^{* *}$ & -0.03 & $-0.17^{*}$ & 0.05 & $0.25^{* * *}$ & $0.17^{*}$ & -0.19 ** & $0.19 * *$ & - & - & - & - & - & - & - & - \\
\hline Listed Target & $-0.19^{* *}$ & -0.08 & $0.23^{* * *}$ & -0.11 & 0.05 & -0.07 & -0.07 & 0.15 & 0.12 & -0.03 & -0.02 & $0.27 * *$ & 0.11 & $-0.20^{* *}$ & $0.16^{*}$ & $0.27 * * *$ & - & - & - & - & - & - & - \\
\hline Deal Size & 0.04 & $0.29 * * *$ & $0.17^{*}$ & 0.04 & 0.01 & $0.23^{* *}$ & 0.01 & $0.25^{* * *}$ & $0.19 * *$ & 0.00 & $-0.15^{*}$ & $-0.26 * * *$ & $-0.18^{*}$ & 0.02 & $0.40^{* * *}$ & 0.13 & $0.22^{* *}$ & - & - & - & - & - & - \\
\hline Related & 0.13 & -0.09 & -0.14 & -0.04 & -0.09 & -0.05 & -0.06 & -0.10 & 0.12 & 0.09 & -0.01 & 0.03 & 0.04 & 0.00 & 0.00 & -0.03 & -0.08 & -0.02 & - & - & - & - & - \\
\hline Payment & -0.13 & 0.11 & 0.04 & 0.07 & 0.03 & $-0.24 * *$ & 0.01 & $-0.40 * *$ & $-0.16^{*}$ & -0.11 & $0.29 * * *$ & -0.13 & -0.14 & -0.01 & -0.05 & -0.03 & 0.05 & 0.04 & -0.05 & - & - & - & - \\
\hline Control & 0.14 & 0.02 & 0.15 & 0.10 & 0.07 & 0.13 & -0.04 & 0.02 & $-0.16^{*}$ & 0.07 & -0.04 & -0.07 & 0.04 & 0.04 & -0.03 & 0.13 & -0.02 & -0.06 & 0.11 & -0.07 & - & - & - \\
\hline Tax & -0.04 & 0.03 & 0.12 & -0.07 & $-0.20^{* *}$ & -0.02 & $0.20^{* *}$ & 0.11 & 0.05 & 0.09 & -0.10 & -0.01 & -0.08 & -0.06 & 0.12 & 0.08 & 0.00 & 0.12 & -0.11 & -0.08 & 0.08 & - & - \\
\hline $\begin{array}{l}\text { Geo } \\
\text { Distance }\end{array}$ & 0.11 & 0.10 & 0.14 & $-0.20^{* *}$ & $-0.23^{* *}$ & -0.15 & $0.33^{* * *}$ & $0.17^{*}$ & 0.12 & 0.15 & -0.11 & 0.06 & $-0.22^{* *}$ & 0.07 & 0.04 & 0.01 & 0.06 & 0.14 & -0.07 & -0.13 & -0.10 & $0.34 * *$ & - \\
\hline International & -0.04 & -0.06 & 0.12 & 0.10 & $0.31^{* * *}$ & 0.03 & $-0.68^{* * *}$ & -0.09 & -0.11 & -0.14 & 0.02 & 0.05 & 0.11 & -0.05 & -0.05 & 0.15 & 0.04 & -0.08 & 0.07 & 0.05 & 0.00 & $-0.59 * *$ & $-0.50^{* * *}$ \\
\hline
\end{tabular}

Note: This table provides the correlation coefficients among the variables indentified and selected in this research. Variable definitions are detailed in section 2.2. Asterisks denote the significance of correlation coefficients: $\mathrm{p}<0.1,{ }^{* *} \mathrm{p}<0.05,{ }^{* *} \mathrm{p}<0.01$. 
Table 3A. Regression results

\begin{tabular}{|c|c|c|c|c|c|c|c|c|c|c|c|c|}
\hline \multirow{2}{*}{ Variable } & \multicolumn{2}{|c|}{ Model 1} & \multicolumn{2}{|c|}{ Model 2} & \multicolumn{2}{|c|}{ Model 3} & \multicolumn{2}{|c|}{ Model 4} & \multicolumn{2}{|c|}{ Model 5} & \multicolumn{2}{|c|}{ Model 6} \\
\hline & {$[-1,+1]$} & {$[-2,+2]$} & {$[-1,+1]$} & {$[-2,+2]$} & {$[-1,+1]$} & {$[-2,+2]$} & {$[-1,+1]$} & {$[-2,+2]$} & {$[-1,+1]$} & {$[-2,+2]$} & {$[-1,+1]$} & {$[-2,+2]$} \\
\hline Intercept & 0.019 & $-0.135^{*}$ & 0.066 & -0.051 & 0.052 & -0.062 & 0.020 & $-0.200^{* *}$ & 0.014 & $-0.217^{* *}$ & 0.081 & -0.143 \\
\hline \multicolumn{13}{|c|}{ Governance measures } \\
\hline Legal & - & - & 0.011 & 0.005 & 0.008 & 0.002 & - & - & - & - & 0.007 & 0.006 \\
\hline Relative G & - & - & -0.003 & 0.000 & - & - & - & - & - & - & -0.039 & -0.014 \\
\hline G Distance & - & - & - & - & 0.001 & 0.001 & - & - & - & - & $0.003^{*}$ & 0.003 \\
\hline Firm G & - & - & -0.049 & $-0.085^{*}$ & -0.051 & $-0.088^{*}$ & - & - & - & - & -0.042 & -0.061 \\
\hline \multicolumn{13}{|c|}{ Cultural measure } \\
\hline C Distance & - & - & - & $\begin{array}{l}- \\
\end{array}$ & - & - & 0.001 & 0.002 & 0.000 & 0.002 & -0.001 & -0.000 \\
\hline \multicolumn{13}{|c|}{ Firm-level characteristics } \\
\hline Cross Listed & 0.015 & 0.010 & 0.020 & 0.015 & 0.021 & 0.016 & -0.007 & -0.014 & 0.003 & -0.014 & 0.010 & -0.002 \\
\hline State Own & 0.002 & 0.005 & -0.001 & -0.003 & -0.001 & -0.003 & 0.004 & 0.002 & 0.004 & 0.002 & -0.001 & -0.002 \\
\hline Tobin Q & -0.003 & -0.005 & -0.003 & -0.006 & -0.003 & -0.007 & -0.004 & -0.009 & -0.006 & -0.010 & -0.006 & $-0.011^{*}$ \\
\hline Pre Perform & $-0.107^{* * *}$ & $-0.214^{* * *}$ & $-0.116^{* * *}$ & $-0.235^{* * *}$ & $-0.123^{* * *}$ & $-0.240^{* * *}$ & -0.065 & $-0.179 * * *$ & -0.060 & $-0.171^{* * *}$ & $-0.077^{*}$ & $-0.195^{* * *}$ \\
\hline Size $\quad$ & -0.009 & 0.020 & -0.013 & 0.013 & -0.012 & 0.013 & -0.006 & $0.030^{* *}$ & -0.011 & $0.025^{*}$ & -0.015 & 0.021 \\
\hline Leverage & 0.021 & -0.015 & 0.036 & 0.015 & 0.038 & 0.018 & 0.023 & -0.018 & 0.034 & -0.005 & $0.055^{*}$ & 0.014 \\
\hline Free Cash Flow & 0.038 & 0.031 & 0.038 & 0.033 & 0.037 & 0.033 & $0.043^{*}$ & 0.041 & $0.041^{*}$ & 0.039 & $0.050^{* *}$ & 0.045 \\
\hline Age & -0.001 & -0.001 & -0.000 & -0.001 & -0.001 & -0.001 & -0.000 & -0.001 & -0.000 & -0.001 & -0.000 & -0.001 \\
\hline Experience & 0.005 & -0.010 & 0.006 & -0.011 & 0.004 & -0.013 & -0.001 & -0.011 & -0.002 & -0.013 & 0.000 & -0.012 \\
\hline Listed Target & -0.016 & $-0.049^{* *}$ & -0.023 & $-0.051^{* *}$ & -0.024 & $-0.052^{* *}$ & -0.017 & $-0.048^{* *}$ & -0.016 & $-0.050^{* *}$ & -0.024 & $-0.055^{* *}$ \\
\hline \multicolumn{13}{|c|}{ Deal characteristics } \\
\hline Deal Size & $0.024^{* *}$ & 0.014 & $0.026^{* *}$ & 0.020 & $0.026^{* *}$ & 0.020 & $0.030^{* * *}$ & 0.026 & $0.027^{* *}$ & 0.024 & $0.028^{* *}$ & 0.023 \\
\hline Related & -0.014 & 0.026 & -0.016 & 0.016 & -0.018 & 0.015 & -0.029 & 0.045 & -0.028 & 0.050 & -0.018 & 0.057 \\
\hline Payment & $0.050^{* *}$ & 0.017 & $0.046^{* *}$ & 0.006 & $0.047^{* *}$ & 0.008 & 0.030 & -0.011 & 0.035 & -0.009 & $0.037^{*}$ & -0.007 \\
\hline Control & 0.010 & $0.065^{*}$ & 0.014 & $0.082^{* *}$ & 0.013 & $0.081^{* *}$ & 0.015 & $0.068^{*}$ & 0.016 & $0.072^{*}$ & 0.009 & $0.065^{*}$ \\
\hline \multicolumn{13}{|c|}{ Country-level characteristics } \\
\hline Tax & -0.006 & -0.010 & -0.008 & -0.015 & -0.006 & -0.012 & 0.001 & -0.014 & -0.001 & -0.015 & -0.007 & -0.024 \\
\hline Geo Distance & - & - & $-\ldots$ & - & $-\ldots$ & - & $\ldots$ & - & 0.000 & 0.000 & 0.000 & 0.000 \\
\hline International & - & - & - & - & - & - & - & - & 0.000 & 0.000 & -0.000 & -0.000 \\
\hline No. of obs. & 138 & 138 & 136 & 136 & 136 & 136 & 122 & 122 & 122 & 122 & 122 & 122 \\
\hline R2 & 0.229 & 0.264 & 0.258 & 0.297 & 0.266 & 0.301 & 0.215 & 0.281 & 0.225 & 0.288 & 0.271 & 0.318 \\
\hline Adjusted R2 & 0.135 & 0.174 & 0.144 & 0.189 & 0.153 & 0.194 & 0.104 & 0.171 & 0.089 & 0.164 & 0.110 & 0.166 \\
\hline F-statistic & $2.433^{* * *}$ & $2.923^{* * *}$ & $2.257^{* * *}$ & $2.749^{* * *}$ & $2.353^{* * *}$ & $2.801^{* * *}$ & $1.933^{* *}$ & $2.559 * * *$ & $1.657^{* *}$ & $2.319^{* *}$ & $1.676^{* *}$ & $2.095^{* * *}$ \\
\hline
\end{tabular}

Note: This table presents regression results of CARs (dependent variable) over 3-day $([-1,+1])$ and 5-day $([-2,+2])$ event windows. Variable definitions are detailed in section 2.2 . Model 1 tests the hypothesis on cross-listing (H1). Model 2 verifies the hypothesis pertaining to the relative governance between two countries ( $\mathrm{H} 2$ ), and Model 3 evaluates the hypothesis pertaining to the governance distance between pair-wise countries (H3). Model 4 evaluates the hypothesis pertaining to the cultural distance (H4), and Model 5 tests the hypothesis regarding the cultural distance between two countries controlling for geographical distance and target country's level of international experience (H5). Model 6 provides comprehensive analyses of all variables used in this research. The t-statistics are suppressed for the lack of space. The asterisks $\left(^{\star}\right)$ denote the significane of coefficient estimates: ${ }^{*} p<0.1,{ }^{* *} p<0.05,{ }^{* *} \mathrm{p}<0.01$. 